\title{
WHY DO SOME MUNICIPALITIES APPLY ACCRUAL-BASED RULES MORE THAN OTHERS? EVIDENCE FROM TURKEY
}

\author{
Selver Seda Ada, Johan Christiaens
}

\section{Introduction}

In recent decades, public sector accounting reforms have been one of the most striking aspects of the adoption of New Public Management (NPM) (Lapsley \& Pallot, 2000; Christensen, 2007; Christensen \& Parker, 2010; Ball \& Craig, 2010; Pollanen \& LoiselleLappointe, 2012). Accrual accounting, which is closely related to public-sector accounting reforms, has been studied in various contexts from various perspectives (Pallot, 1994; Shand, 1990; English, Guthrie, \& Carlin, 2000; Ryan, 1998; Carnegie \& Wolnizer, 1995; Barton, 1999; Carnegie \& Wolnizer, 1999; Salinas, 2002; Carlin, 2005). However, the literature has presented limited evidence of the adoption of accrual accounting in emerging countries (e.g., the role of accountants in accounting reform in Malaysia, Nor-Aziah \& Scapens (2007) and Saleh (2007); the accounting reform model in Thailand, Upping \& Oliver (2012); accounting reform in Indonesia, Marwata \& Alam (2006); the adoption of accrual accounting in Indonesia, Harun \& Robinson (2010); and local government accounting reform in Indonesia, McLeod \& Harun (2014)).

Administrative reforms such as the implementation of accrual-based rules are particularly encouraged by the European Union (EU), the International Monetary Fund (IMF) and the World Bank (WB). Developing countries are pressured to adopt administrative reforms that the international organizations considers best practice (Andrews, 2012). Because these organizations can be viewed as external actors, the above-referenced reforms can be characterized as top-down reforms. However, it is important not to overlook local governments - which can be viewed as internal actors - as practitioners of rules, standards and reforms (Sezen, 2011, p. 322). There are several important reasons that the emerging country of Turkey represents an interesting and important case of policy transfer, including (for example) the implementation of accrual accounting at the local government level. First, Turkey does not fit into either Europe or the Middle East (Müftüler Bac, 2005, p.18), although it will soon join the EU. Turkey's long road to EU membership affects all levels of society, including local governments, and most of the EU's directives will be implemented at the local level. To the best of our knowledge, the EU's effect on the implementation of accrualbased rules has not been studied at the level of local government. Second, emerging countries have a rapidly increasing population. Turkey's population was 56.4 million in $1990,67.8$ million in 2000, 73.2 million in 2010 and 77.6 million in 2014. Rapid urbanization, a growing labor force and high youth unemployment are additional social factors that have implications for social policy (Sözen \& Shaw, 2002, p. 478). Because of this rapid urbanization, new municipalities are being created to address societal needs. In this context, our research has been stimulated by the implementation and consequences of accounting reforms in newly established municipalities; to the best of our knowledge, this has never been studied before.

The effects of these accounting reforms - including municipal size, municipal wealth, citizen education level, staff education level, debt ratio, external audits, implementation of EU-funded projects and newly created municipalities - have resulted in various levels of compliance with accrual-based rules among Turkey's new municipalities. This leads us to question why some municipalities demonstrate a heightened level of compliance with accrual-based rules. Examining 102 Turkish municipalities, we employ institutional theory and resource-dependence theory to increase our understanding of the factors that affect the 
level of compliance with accrual-based rules. We performed a multiple regression analysis (Cohen, Cohen, West, \& Aiken, 2013) and found that the most influential predictors of the level of compliance are as follows: external audit, implementation of EU-funded projects and being a new municipality.

Our paper makes two primary contributions. First, we contribute to the literature on governmental accounting by adding institutional factors other than economic variables that affect the level of compliance. This addresses an important gap in the literature identified by Carpenter and Feroz (2001, p. 593): “... Another follow-up to this work would be an extension of the extant governmental accounting literature incorporating institutional variables in a statistical model... We suspect that economic variables based on size, fiscal stress and debt levels will no longer continue the significant variables..." In this sense, our study is one of the first to show that the level of compliance with accrual-based rules is increased not only by being a newly founded municipality but also by implementing EU-funded projects. Second, we contribute to the literature in that our findings may help both politicians and government managers to identify resource dependency as an institutional pressure; coercive institutional pressure to implement accrual-based rules may become a potent force to increase the level of compliance both when a supreme audit institution controls and when there is resource dependence on an international body (i.e., the $E U)$. One practical implication of our findings is that compliance levels are positively associated both with the implementation of EU-funded projects and with newly founded municipalities.

Accordingly, part one presents the theoretical framework. Part two describes the research question and hypothesis development. Part three presents the development of the compliance index; part four presents the data. Part five analyses the study's results and is followed by the discussion and conclusion.

\section{Theoretical Framework}

Various theoretical frameworks may be used to study the adoption of accrual accounting in the public sector. Antipova and Bourmistrov (2013), Carpenter and Feroz (2001), Guler, Guillen and Macpherson (2002), Greening and Gray (1994), and Guo (2007) have used institutional theory (DiMaggio \& Powell, 1983) and resource- dependence theory (Pfeffer \& Salancik, 1978) to gain insight into several aspects of publicsector behavior. We also borrow theoretical ideas from institutional theory and resourcedependence theory to understand - with the help of our hypothesis - the factors that affect the level of compliance with the prescribed accrual-based rules.

Institutional theory views organizations as operating within a social framework of norms, values and taken-for-granted assumptions about what constitutes appropriate or acceptable economic behavior (Carpenter \& Feroz, 2001). According to Scott (1987, p. 468), organizations conform to institutional changes in their environment because they are rewarded with increased legitimacy, resources and survival ability. The institutional environment of local governments - including central government, educational institutions, accounting professionals, employees, creditors, and citizens - may help reform to gain legitimacy and external support from both external bodies and internal participants (Carpenter \& Feroz, 2001). Dimaggio and Powell (1983) identify three mechanisms for institutional isomorphic change: coercive isomorphism, normative isomorphism and mimetic isomorphism. Coercive isomorphism arises out of political influence and the problem of legitimacy; it is characterized by the imposition of rules to adopt the same types of changes in both structures and processes. The EU's decision to adopt international standards may imply a coercive decision (Gomes, Fernandes, \& Carvalho, 2015). Mimetic isomorphism results from standard responses to uncertainty and defines the adoption of changes that are experienced by other organizations. Normative isomorphism, which is associated with professionalism, refers to the strong influence and pressure exercised by professional organizations. The influence of the International Federation of Accountants (IFAC) and the International Public Sector Accounting Standards Board (IPSASB) may be examples of normative forces pressing the adoption of international public-sector accounting standards (IPSAS) (Gomes et al., 2015). These isomorphic processes cause organizations to become similar, thus facilitating their transactions with one another. Although the three mechanisms may be derived under different conditions and have different outcomes, they tend to "intermingle in an empirical setting" (DiMaggio \& Powell, 1991, p. 67). Notwithstanding the fact that each mechanism 
involves a separate process, two or more isomorphic pressures can operate at the same time; in such a situation, it is difficult to clearly identify the effects of each type of pressure.

Prior research also confirms the importance of these concepts to gaining insight from accounting changes. According to Carpenter and Feroz (2001), accounting reforms in the United States (USA) can be understood in terms of coercive isomorphic pressures from the credit markets, whereas late adoption seems to be associated with the combined influences of normative and mimetic institutional pressures (p. 588). In the Canadian case, the implementation of accrual accounting can be "largely attributed to coercive and normative influences of the Office of the Auditor General of Canada and mimetic isomorphism with other members of the federal government's organizational field" (Baker \& Rennie, 2006, p. 83). Gomes et al. (2015) conclude that "the reform stimuli are mainly influenced by the institutional and political context and a combination of coercive, normative and mimetic forces" in their contribution to the Portuguese case (p. 279). All three isomorphic mechanisms may influence organizational behavior. That notwithstanding, because the government's introduction of new accounting and reporting standards is the most direct mechanism of institutional diffusion, this paper draws largely on coercive isomorphism to explain compliance levels. Coercive isomorphism results when organizations are subjected to both formal and informal pressures by other organizations upon which it is dependent (Dimaggio \& Powell, 1983). In our study, organizations experience external pressure that is exerted by international bodies such as the IMF, the EU, and the WB. Such pressure may be felt as force, persuasion or an invitation to collude (Dimaggio \& Powell, 1983).

In addition, our study adopts the perspective that resource dependence is a potent form of coercive institutional pressure for change associated with the implementation of accrualbased accounting rules. The fundamental assertion of resource-dependence theory is simply stated by Pfeffer and Salancik (1978): The key to organizational survival is the ability to both acquire and maintain sources (p. 2). Organizations are not completely autonomous; instead, their resource needs cause them to be dependent on their environment.
An organization's degree is determined by the importance and concentration of the resources that it is provided (Froelich, 1999). To understand organizational decision making, the resource-dependence perspective focuses primarily on external factors (Carpenter \& Feroz, 2001). Mizruchi and Fein (1999) suggest that pressure from external resource providers results in coercive isomorphism and "is thus analogous to formulations of the resource dependency model in which organizations are viewed as constrained by those on whom they depend for resources" (p. 657). Resource dependence results in accounting changes influenced by coercive isomorphic pressure. Thus, the theoretical arguments related to resource dependence represent a particular form of coercive isomorphic pressure (Carpenter \& Feroz, 2001, p. 573).

\section{Research Questions and Hypothesis Development}

In Turkey, discussions about strong central power and weak local governments, the lack of autonomy for local governments and the need to strengthen democracy are common among scholars (Sezen, 2011, p. 329). Primarily for this reason, the Turkish government decided to strengthen local governments as a key priority. Accordingly, between 2004 and 2010, special laws and regulations pertaining to local governments were introduced (Sözen, 2012). Consistent with international trends, on December 24, 2003, the "Public Financial Management and Control Law, No: 5018" (PFMCL) was issued as a key component of financially strengthening local governments. According to that law, both governmental accounting reform (which became effective for local governments at the beginning of 2006) and the cash-based "Government Accounting by Law" (which had existed for 14 years) were abolished. An accrual-based government accounting system has now been implemented in all institutions, including centralized governments, social security institutions and local governments. The law's most important reform is the introduction of a uniform accounting system on an accrual basis and an annexed budget administration in accordance with international accounting and reporting standards.

Little attention has been paid to the level of municipalities' compliance with the accrual 
accounting regulations that have been prescribed by the Local Authorities Budget and Accounting Regulation since 2006. Most of the Turkish studies about the process of implementing accrual accounting are exploratory because of the difficulty of collecting data about Turkish municipalities. Although municipalities are supposed to upload their financial accounts to their official websites, they rarely do so. According to Turkyener (2011), there are many errors in municipalities' financial reports. In addition, many studies have shown that the failure in accounting standards is caused by numerous problems in the implementation process (Christiaens \& Rommel, 2008). Accordingly, several hypotheses have been formulated to determine the reasons for the level of compliance in the public sector (Evans \& Patton, 1983; Ingram, 1984; Robins \& Austin, 1986; Evans \& Patton, 1987; Giroux, 1989; Dixon et al., 1991; Cheng, 1992; Allen \& Sanders, 1994; Pina \& Torres, 1996; 2003; Coy et al., 1994; Coy \& Dixon, 2002; Christiaens, 1999; Weets \& Jegers, 2000; Giroux \& McLelland, 2003; Christiaens \& Vanhee, 2003; Da Costa Carvalho, et al., 2007; Verbruggen, 2011). Although these studies' investigations have resulted in valuable insights and interesting hypotheses, little has been produced with respect to emerging-country characteristics. Therefore, insight into whether newly founded municipalities and the implementation of EU projects affect compliance levels could be an important factor in the success of emerging countries. In addition, developing countries are countries in which ideas move in one direction and practice moves in another (Ouda, 2004). A developing country's characteristics may affect other characteristics. Consequently, we not only determined compliance levels but also tested our hypothesis to monitor the factors that affect compliance levels. Against this background, we formulate the research question as follows:

$R Q$ : Why do some Turkish municipalities apply accrual-based rules more than others?

Accordingly, working from the research question and previous studies, we have formulated the following hypotheses, which focus on the specific variables of emergingcountry characteristics. To improve the analysis, traditional variables are added as control variables to test whether they have the same impact on Turkish local governments.

The first emerging-country variable is Turkey's increasing population and its effect on local government policy. The population of Turkey was 56.4 million in 1990, 67.8 million in 2000, 73.2 million in 2010 and 77.6 million in 2014. Despite this rapid increase, the proportion of the population living in rural areas is decreasing while the proportion is increasing markedly in both the provinces and the district centers; thus, the proportion of the population living in the provinces and district centers was $59 \%$ in $1990,64.9 \%$ in $2000,76.3 \%$ in 2010 and $91.8 \%$ in 2014 . As legitimate policy partners with the central government, local governments work to formulate policies in the midst of these sociodemographic changes. To manage these difficulties in areas where the population is rapidly increasing, municipalities are being created; for example, 13 metropolitan municipalities were created on November 12, 2012. These new municipalities require more financial and human resources because they are required to enact changes such as establishing guest houses for women and children and making new staff assignments. Thus, we hypothesize that to acquire legitimacy from the institutional environment - and thus more resources for new policies and survival municipalities founded between 2006 and 2014 will have a higher level of compliance (Meyer \& Rowan, 1977; DiMaggio \& Powell, 1983). Pressure from external resource providers may result in coercive isomorphism during the process of obtaining these resources (Carpenter \& Feroz, 2001, p. 572). To the best of our knowledge, no study has analyzed the compliance level of new municipalities. Therefore,

H1: The level of compliance is positively associated with the type of the municipality.

Another emerging-country variable relates to Turkey's EU accession. Turkey's path to EU membership started with the 1999 Helsinki Summit, at which the European Council declared that "Turkey is a candidate country destined to join the EU on the basis of the same criteria as applied to the other candidate states." Based on that declaration, to become an EU member, Turkey had to fulfill the political requirements of the Copenhagen criteria (Müftüler-Baç, 2008). At its 2002 Copenhagen summit, the European Council stated, "If Turkey fulfils the Copenhagen criteria, the European Union will open accession negotiations without delay." During this long journey, "Turkey's accession depends 
on its ability to adopt fully the EU acquis in its entirety and to remain committed to democratic principles and procedures that the EU stands upon" (Müftüler-Baç, 2008, p. 201). The EU is committed to financially supporting Turkey in this difficult task on its path to membership. The initial objective of the EU's financial support for Turkey is the extension of an area of peace, stability and prosperity within and beyond Europe; for the most part, Turkey has tended to comply in the area of education (http://www. avrupa.info.tr/AB_Mali_Destegi.html). The EU usually gives financial support for project implementation. Most of the EU's directives are to be implemented at the local level, and EU support benefits society at all levels, including that of local government. Turkish municipalities also apply to receive funding for EU projects. Following a consultation process between the EU and Turkish authorities, projects are selected and included in the annual national program. These programs will receive EU funds. When an institution's project is funded by the EU, its related institutions must report their financials to the EU according to international financial reporting standards. This requirement is the basis for our hypothesis that the EU engages in a form of coercive isomorphism. In addition, according to resource-dependence theory (in which resources can be money, human resources, etc.), organizations survive only if they both manage and monitor their dependencies (Hillman, Withers \& Collins et al., 2009). Accordingly, we aim to measure - for the first time - whether the implementation of an EU-funded project has an impact on the level of compliance. Therefore,

H2: The level of compliance is positively associated with the implementation of EUfunded projects.

The effect of our first control variable - the size of the municipality - on the compliance level is disputed by several studies. According to Allen and Sanders (1994), city size does not affect disclosure, whereas Christiaens (1999) has discovered that city size has a significant positive effect on the level of compliance. In contrast, Da Costa Carvalho et al. (2007) have claimed that the size of the municipality has a negative effect on compliance. In addition, many studies indicate no relationship between compliance and municipality size (Evans \& Patton, 1983; Robbins \& Austin, 1986; Ingram
\& DeJong, 1988). Institutionalization refers to organizations gaining legitimacy by adopting elements from the institutional environment to survive (Meyer \& Rowan, 1977; DiMaggio \& Powell, 1983). Here, we hypothesize that larger municipalities' more substantial financial and human resources lead to a higher level of compliance. Following the standard statistical recommendation, we tested the effect of population on compliance level with a logarithmic transformation. Therefore,

H3: The level of compliance is positively associated with the size of the municipality.

The effect of staff on the level of compliance has been analyzed by many governmental studies in terms of the number of staff members, educational level, professionalism, etc. (Ingram, 1984; Robbins \& Austin, 1986; Christiaens, 1999, Christiaens \& Peteghem, 2007; Da Casto Carvalho et al., 2007). We tested the effect of staff members' education level on compliance level. The compound level of education has been measured by the formula $\left(2 * L T+1{ }^{*} S T+0 * S\right) /(L T+S T+S)$, in which LT stands for university degree, ST stands for high school and S stands for secondary education (Christiaens, 1999; Christiaens \& Peteghem, 2007). According to Christiaens (1999), one advantage of this approach is comparability among municipalities, whereas arbitrarily chosen weighting coefficients are a disadvantage. Here, we hypothesize that more highly educated staff will have more knowledge of accrual accounting rules. Therefore,

H4: The municipal accounting staff's educational level positively affects the level of compliance.

Environmental factors are also relevant to explaining differences in conformity among municipalities. Arguably, a democratically elected local government must respond to its citizens' needs ( $\mathrm{Da}$ Casto Carvalho et al., 2007). As highlighted by Chan (2006), both citizen awareness and socioeconomic status may be relevant to the adoption of accountingsystem changes. Accordingly, this hypothesis is proxied by assuming that citizens who live on a municipality's borders and have a higher educational level demand more information; the compliance level is therefore higher because people with higher educational levels prefer to acquire/obtain more detailed and transparent 
information. (The level of education completed in higher education refers to the percentage of citizens who have (at minimum) graduated from university.) In addition, a resource dependence relationship exists between the municipality and the citizen as a taxpayer. Therefore:

H5: The level of compliance is positively associated with the educational level of the municipality's residents.

Profitability may be a factor that is crucial to influencing the level of compliance (Street \& Gray, 2002). Municipalities can also be financed with debt. Financial institutions examine financial statements when making loans. Therefore, it is assumed that the level of compliance is higher when a municipality's reliance on debt is greater. According to the resource-dependence theory, organizations try to increase their compliance with the requirements of their resource providers. (Froelich, 1999). The findings of Christiaens
(1999) show that reliance on debt negatively affects the compliance level. However, Da Casto Carvalho et al. (2007) explain differences in municipalities' compliance in terms of financial position, particularly the availability of financial resources. We hypothesize that relying on loans strongly and visibly increases the level of compliance; this increase is also in line with resource-dependence theory (Pfeffer \& Salancik, 1978). Therefore,

H6: Compliance levels are positively associated with reliance on debt.

Several studies (Robbins \& Austin, 1986; Cheng, 1992; Christiaens, 1999) test wealth in terms of revenue per capita based on Ingram (1984), who assumes that state wealth has a positive relationship with increased disclosure. Moreover, according to Marti and Kasperskaya (2015), countries with high level of economic developments are more likely to characterized by the presentation of accrual based financial

\section{Tab. 1: Model variables}

\begin{tabular}{|c|c|c|c|c|}
\hline Variable & Reference & $\begin{array}{l}\text { Expected } \\
\text { Sign }\end{array}$ & Measure & Source \\
\hline EU project & Proposed by the current study & $?$ & dummy varible & $\begin{array}{l}\text { activity reports of } \\
\text { municipalities }\end{array}$ \\
\hline $\begin{array}{l}\text { Newly founded } \\
\text { municipality }\end{array}$ & Proposed by the current study & $?$ & dummy variable & $\begin{array}{l}\text { Union of Municipalities of } \\
\text { Turkey }\end{array}$ \\
\hline $\begin{array}{l}\text { Municipal staff } \\
\text { education }\end{array}$ & $\begin{array}{l}\text { Ingram, 1984; Christiaens, 1999, } \\
\text { Christiaens and Peteghem, 2007; } \\
\text { Da Casto Carvalho et al., } 2007\end{array}$ & + & $\begin{array}{l}\text { the level of the } \\
\text { staff's education }\end{array}$ & $\begin{array}{l}\text { activity reports and surveys } \\
\text { sent to municipalities where } \\
\text { necessaire }\end{array}$ \\
\hline $\begin{array}{l}\text { Education level of } \\
\text { citizens }\end{array}$ & $\begin{array}{l}\text { Ingram, 1984; Christiaens, 1999; } \\
\text { Da Costa Carvalho et al., } 2007\end{array}$ & + & $\begin{array}{l}\text { percentage of } \\
\text { citizens graduated } \\
\text { from at least } \\
\text { university }\end{array}$ & TurkStats \\
\hline Municipal size & $\begin{array}{l}\text { Allen and Sanders, 1994; } \\
\text { Christiaens, 1999; Da Costa } \\
\text { Carvalho et al. 2007; Robbins and } \\
\text { Austin, } 1986\end{array}$ & $+1-$ & population & TurkStats \\
\hline Reliance on debt & $\begin{array}{l}\text { Christiaens, 1999; Giroux and } \\
\text { McLelland, 2003; Da Costa } \\
\text { Carvalho et al. } 2007\end{array}$ & $?$ & $\begin{array}{l}\text { financial leverage } \\
\text { ratio }\end{array}$ & $\begin{array}{l}\text { financial statements of } \\
\text { municipalities }\end{array}$ \\
\hline Municipal wealth & $\begin{array}{l}\text { Ingram, 1984; Robbins and Austin, } \\
\text { 1986; Cheng, 1992; Christiaens, } \\
\text { 1999; Giroux and McLelland, } 2003\end{array}$ & + & revenue per capita & $\begin{array}{l}\text { financial statements of } \\
\text { municipalities, TurkStats }\end{array}$ \\
\hline External audit & $\begin{array}{l}\text { Robbins and Austin, 1986; Windels } \\
\text { and Christiaens, } 2006\end{array}$ & + & dummy variable & $\begin{array}{l}\text { activity reports of } \\
\text { municipalities, Turkish Court } \\
\text { of Account }\end{array}$ \\
\hline
\end{tabular}


statements. We also hypothesize that the level of compliance will be higher in wealthier municipalities because of the likelihood that there will be better qualified staff, that more attention will be given to financial reporting, etc. Therefore:

H7: The level of compliance is positively associated with the revenue per capita.

Our final hypothesis addresses external public sector audits, which are NPM's "bread and butter" (Buylen \& Christiaens, 2014). Despite the importance of external audits, few studies have addressed them (Robbins \& Austin, 1986; Christiaens, 1999; Windels \& Christiaens, 2006). It is assumed that increased compliance levels will be caused by external auditors' assessments. An external audit report shows how efficiently a municipality manages its resources, which may be an indicator for resource suppliers. Particularly in a country such as Turkey, where there is a great deal of power distance (Hofstede, 1983), it can be hypothesized that the level of compliance is higher when a municipality is subject to an external audit. Therefore,

H8: Compliance levels are positively associated with the execution of external audits.

\section{Development of the Compliance Index}

According to Pollitt (2001), there are four stages of NPM adoption: discourse, decision making, real organization practice and impact on public organizations. Our study addresses the third stage - real organization practice - with the help of a compliance index.

Using an index to measure compliance with accounting standards is a time-honored methodology in public-sector accounting research. Methodologically, this study is based on previous studies that have developed disclosure and compliance indices. In 1984, Ingram provided preliminary evidence about the association between economic factors and cross-sectional variations in accounting practices of state governments in the USA by analyzing 12 items in a disclosure index. The results showed a higher level of disclosure in states with voter coalitions, administrative monitoring and evidence of administrative ability. Ingram's study is a milestone in governmental accounting research, and several studies have used the same approach (Disclosure index:
Robins \& Austin, 1986; Giroux, 1989; Cheng, 1992; Allen \& Sanders, 1994; Tooley \& Guthrie, 2007; Stanley, Jennings \& Mack, 2008; Cooke's index: Pina \& Torres, 1996; Pina \& Torres, 2003; Accountability index: Dixon, Coy \& Tower, 1991; Coy, Tower \& Dixon, 1994; Coy \& Dixon, 2002; Ryan, Stanley \& Nilson, 2002; Compliance index: Christiaens, 1999; Weets \& Jegers, 2000; Giroux \& McLelland, 2000; Christiaens \& Vanhee, 2003; Da Costa Carvalho, Camoes, Jorge \& Fernandes, 2007; Christiaens \& Van Peteghem, 2007).

Based on this body of literature, Christiaens (1999), Da Costa Carvalho et al. (2007) and Christiaens and Van Peteghem (2007) have turned their attention to the implementation of business-like accounting principles in their public-sector compliance index. Christiaens (1999) has included in the compliance index not only transparency and technical issues but also other features related to compliance with newly introduced accounting and reporting standards. Transparency issues consist of timeliness, disclosure, formalistic requirements, adequacy and usefulness elements, whereas technical issues consist of completeness, cutoff, classification, mechanical accuracy and compensation elements. The index is a quantitative measure of the qualitative aspects of both financial accounting and reporting. Similar to Christiaens (1999), Coy and Dixon (2004), Da Costa Carvalho et al. (2007), and Christiaens and Van Peteghem (2007), we used the compliance index to measure each municipality's level of compliance. The elements in the index, which consist of 39 elements, have been measured dichotomously. The results of the compliance index determined the dependent variable to be used in the multiple regression.

\section{Data}

There are 1,397 municipalities in Turkey, 428 of which have a population of more than 25,000 . We selected the municipalities with populations of more than 25,000 because it is difficult to access small municipalities' annual accounts. An a priori power analysis using $\mathrm{G}^{*}$ Power 3.1 (Faul, Erdfelder, Buchner, \& Lang, 2009) demonstrated that 74 municipalities would be needed to detect the effects ( $f=0.15$ ) with $95 \%$ power (1- $\beta$ ) using linear multiple regression with 8 predictors and alpha at 0.05 . In this study, we tested 102 municipalities' levels of compliance 
Tab. 2:

Data set

\begin{tabular}{l|c|c}
\multicolumn{1}{c|}{ Population } & Number of the municipalities & Data set \\
\hline $25,000-49,999$ & 108 & 26 \\
\hline $50,000-99,999$ & 109 & 17 \\
\hline $100,000-249,999$ & 120 & 22 \\
\hline $250,000-499,999$ & 61 & 26 \\
\hline over 500,000 & 30 & 11 \\
\hline Total & $\mathbf{4 2 8}$ & $\mathbf{1 0 2}$ \\
\hline
\end{tabular}

Source: own

with accrual accounting rules prescribed by laws and regulations; this is a much larger sample than that proposed by $\mathrm{G}^{*}$ Power 3.1. The sample consisted of 102 municipalities in all regions of Turkey that were randomly selected from the 428 municipalities referenced above.

The annual reports that we analyze are taken from the municipalities' annual activity reports. However, some of the municipalities in the sample did not provide their activity reports on the Web. In that situation, annual reports were provided by the Court of Accounts. Secondary data, such as population, age structure and the education level of citizens, were provided by the Turkish Statistical Institute (TurkStat). To measure the staff number and the education level of the staff where that information was not provided in the annual activity reports, a brief online questionnaire was sent to the municipalities pursuant to the "Right to Obtain Information". Municipalities were asked to give information about the number of staff members, their educational levels, and the head of finance's educational level.

\section{Results}

\subsection{Compliance index}

To calculate each municipality's level of compliance, we adopted the compliance index used by prior studies, adding items specific to Turkey. The average score on the compliance index for each municipality, in percentage terms, is calculated by multiplying each score by 100 and dividing by 39 . As a result, according to our descriptive statistics, we found a mean of

\section{Tab. 3: Compliance index results}

\begin{tabular}{l|c}
\multicolumn{1}{c|}{ Item } & Average \\
\hline \multicolumn{1}{c}{ Transparency } & \\
\hline Timeless & $67.8 \%$ \\
\hline Disclosure & $52.0 \%$ \\
\hline Formalistic Requirements & $65.5 \%$ \\
\hline Adequacy and usefulness & $80.0 \%$ \\
\hline Technical Issues & \\
\hline Completeness & $47.7 \%$ \\
\hline Cut-Off & $26.5 \%$ \\
\hline Classification & $99.3 \%$ \\
\hline Mechanical Accurancy & $52.5 \%$ \\
\hline Compensation & $59.8 \%$ \\
\hline Total & $61.2 \%$
\end{tabular}


$61.2 \%$, with a standard deviation of $13.7 \%$ and a median of $60.5 \%$. In addition, the average figures for each component are disclosed in the table below.

The average "cutoff" is the lowest component, with a mean of 26.5 percent. As seen from the compliance index, the cutoff component consists of "accrued charges disclosed" and "accrued income disclosed." According to our findings, few municipal accountants use accrued income and accrued charge accounts, perhaps due to a lack of experience and training in accrual accounts. In addition, provisions for employment termination benefits are not accrued to the related accounts. This result shows relative failure in the implementation of accrual-based rules. Conversely, the most-used component is the "classification" component, which consists of sign assets, possibly because of the ease of understanding sign assets.

\subsection{Regression Equation Results and Interpretation}

We used multiple regression (Cohen et al., 2013) to test our model. Each item in the model was given equal weight because there is no document showing that any item has more of an effect than another. In addition, although each item measures quite different concepts, our statistical results showed that they explain $54.6 \%$ of the dependent variable. In the following table, the regression results of our study are presented.

The observed $\mathrm{F}$ statistic of the regression is 13.975 , and significance at alpha $(=0.0001)$ demonstrates an acceptable standard of accuracy. The variance inflation factors (VIF) are calculated, and there is no multicollinearity threat for any of the predictors, because all of the VIFs were $<2$. Given the normal distribution of the index, the standardized regression coefficients and their associated level of significance are also presented in the table.

\section{Tab. 4: Regression results}

\begin{tabular}{l|c|c}
\multicolumn{1}{c|}{ Surrogates } & $\begin{array}{c}\text { Standardized Coefficient } \\
\text { (Beta) }\end{array}$ & Significance (p) \\
\hline Municipal size & 0.138 & $0.062^{*}$ \\
\hline Newly founded municipality & 0.155 & $0.031^{* *}$ \\
\hline Staff education level & -0.070 & 0.409 \\
\hline Citizens' education level & 0.132 & $0.083^{*}$ \\
\hline EU project implementation & 0.267 & $0.002^{* *}$ \\
\hline Reliance on debt & 0.016 & 0.839 \\
\hline Municipal wealth & -0.025 & 0.749 \\
\hline External audit & 0.450 & $0.000^{* *}$ \\
\hline
\end{tabular}

Source: own

Note: * significant at $\alpha=10 \%,{ }^{* *}$ significant at $\alpha=5 \%, \mathrm{R}^{2}=0.546$

Based on these results, the most influential predictors for the level of compliance are as follows: (1) newly founded municipalities; (2) implementation of an EU-funded project; (3) external audit.

As an emerging country variable, we tested whether there is an association between newly founded municipalities and compliance level. According to our results, being a newly established municipality emerges as a very significant explanatory variable in the model, affecting the level of compliance $(b=0.071, \beta=$ $0.155, p=0.031)$. An explanation for this high level of compliance may be that organizations that are pursuing legitimacy select among alternatives based on efficiency considerations 
when their organization field is being founded or reorganized (Palmer, Jennings, \& Zhou, 1993 , p. 104), which primarily reflects the influence of normative isomorphism (DiMaggio \& Powell, 1983). It appears that newly founded municipalities adopt structures that are perceived as legitimate by other organizations in the same field regardless of those structures' content. In addition, newly founded municipalities that are experiencing fiscal stress in the implementation of new policies (such as establishing guest houses for women and children and making new staff assignments) may rely on accrual-based rules to gain more legitimacy for the purpose of acquiring shortterm financing. This evidence is an important condition that affects the potency of coercive isomorphic pressure leading to higher levels of compliance. However, we must exercise caution in interpreting these results. As noted by DiMaggio and Powell (1991), it is difficult to clearly identify their effects.

Another emerging country variable, the implementation of an EU project, is a very significant predictor $(b=0.074, \beta=0.267$, $p=0.002$ ) of the level of compliance, because the EU demands financial statements that are in compliance with international financial reporting standards. If the funded municipalities do not fulfill the required reporting rules, they will not be able to obtain grants from the EU, which makes them dependent on the resources provided by the EU. This evidence underlines the presence and the potency of institutional pressure, probably in the form of coercive isomorphism based on resource dependency. In other words, institutional pressure may work with other forms of pressure such as resource dependency (Mizuchi \& Fein, 1999). Another possible explanation for this strong effect could be that the accountants who work for the EU projects' financial reporting are trained in related accounting standards. We infer this conclusion from the organized workshops and seminars. Beneficiaries of EU grants participate in both workshops and free webinars that help them to accurately report their financials (http://www.abgs.gov.tr/index.php?p=45646\&l=1). In addition, representatives of central governments emphasize the importance of the EU projects. This evidence emphasizes the institutional context and external pressure as one of the most important reasons to increase compliance with accrual-based rules. In addition, this evidence reinforces institutional thinking in which changes are associated with the need for legitimacy and external support for the resources (Carpenter \& Feroz, 2001; Gomes et al., 2015).

As shown by the regression results, the variable external audit $(b=0.123, \beta=0.450$, $p=0.000$ ) is the most significant predictor of the level of compliance. This may be a consequence of the fact that in terms of audits, the Turkish Court of Accounts is the institution that has the most influence on the municipalities, which validates the idea that coercive isomorphism has an influence on municipalities' willingness to comply with the rules. Organizations are also driven to a high level of financial reporting compliance when they are audited by institutions that affect the provision of resources. An external report on a municipality by the Turkish Court of Accounts also reflects that municipality's quality, which influences the subsidies granted by the government. This high level of compliance shows that the audit environment - not just accounting standards must be modified to induce improved disclosure (Ingram \& Copeland, 1981). In addition, although the internal audit system is found in each municipality, the compliance level is increased in municipalities where the external audit was carried out.

With respect to the size effect, our regression results indicate that municipality size has a positive significant effect ( $b=0.000, \beta=0.138, p=0.062$ ) on the level of compliance. Several studies have shown that the compliance level is higher in larger cities (Da Costa Carvalho et al., 2007; Ingram \& DeJong, 1987; Christiaens, 1999). This confirms that large organizations adopt elements from the institutional environment both to gain more legitimacy from the actors in their external environment (DiMaggio \& Powell, 1983) and to sustain opportunities for acquiring resources. Another possible explanation is that large municipalities may use more complicated information systems, thus disclosing moretransparent information (Bunget, Blidisel, Feleaga, \& Popa, 2014).

In contrast to the findings of $\mathrm{Da}$ Casto Carvalho et al. (2007) and Ingram (1984), it is interesting that our results did not support a relationship between staff educational level and compliance level $(b=-0.053, \beta=-0.070$, $p=0.409$ ). A few studies have demonstrated 
a similar dissociation between staff education and compliance level (Christiaens, 1999). Differences in country characteristics may account for this discrepancy. In our study, we focused on educational level as measured by a person's number of degrees. Rather than focusing on school degrees, we could focus on the level of accounting knowledge, which may be more related to the compliance level. However, it is very difficult to test accounting knowledge.

The hypothesis that citizens' educational level $(b=0.305, \beta=0.132, p=0.083)$ enhances the level of compliance has also proven to be well founded. According to our results, the educational level of a municipality's citizens positively affects the municipality's compliance level, which overlaps with the findings of $\mathrm{Da}$ Casto Carvalho et al. (2007). Law no: 4982 (the right to obtain information) provides that everyone has the right to obtain information about the activities of all public entities, including local governments. However, clearly citizens must be aware of this right if they are to request information. An obvious explanation for this result is that citizens with higher educational levels would like to acquire more detailed and transparent information, and they are more aware of their rights (http://siteresources. worldbank.org/INTBELARUS/Resources/eng. pdf). However, we must exercise caution in interpreting these results because we only used years of completed education; we did not focus on profession, gender, etc. Moreover, income per citizen $(b=-0.000, \beta=-0.025, p=0.749)$ in a municipality has no effect on the level of compliance (Robbins \& Austin, 1986).

Reliance on debt $(b=0.007, \beta=0.016$, $p=0.839$ ) is a variable that has no effect on the level of compliance. For this hypothesis, we tested the association between reliance on short- and long-term debt (financial leverage ratio) and the level of compliance. We hypothesized that reliance on debt would lead to a higher level of compliance. However, according to our regression results, there is no significant effect. This result contradicts the resource-dependence theory but is in line with some of the findings in the literature. As in the Belgian case (Christiaens, 1999), it is possible that Turkish municipalities are less sensitive to financial markets and credit institutions because of the special character of the II Bank, which lends only to local governments to meet their financing needs in Turkey; the significance of this arrangement for local governments is primarily due to the II Bank's low interest rate compared to other banks. The municipalities may take the II Bank for granted.

Although accrual accounting-based rules were implemented nearly ten years ago, more time may be required for local governments to internalize them. "Moreover, the gap between NPM-like thinking and local governance logic, as inciting part for the change, seems too large to overcome and we must ask ourselves whether municipalities can truly incorporate the NPM style work into their work" (Buylen \& Christiaens, 2014). It seems that the changes in the accounting system have been implemented for the benefit of the Turkish government's image, especially in the eyes of international bodies. These top-down reforms may fit the political agenda very well, but the practitioners of the related rules have noted the policy's consequences. We infer this conclusion from the observation that an increase in compliance levels in the event of an EU-funded project and an external audit represent pressures from outside the organization.

Finally, we must state that although our study explains some variance for the municipalities' level of compliance, there remains a large gap to consider. Furthermore, we acknowledge that our study have several limitations. First, we only tested the municipalities whose population is over 25,000 due to problems accessing information from smaller municipalities. However, smaller municipalities are in the majority in Turkey. Second, we acknowledge that our results are confined to the selected hypothesis tested in the study. Third, we calculated the compliance index dichotomously without considering the items. Moreover, it would be useful to apply the results to other emerging countries.

\section{Conclusion}

This article sheds light on the factors that affect the level of compliance with the accrual-based rules for municipalities, an undervalued but very prominent group among local governments. To help both public managers and politicians, our study shows that some factors clearly help increase the level of compliance: the most influential factors are the external audit $(<0.05)$, the implementation of an EU-funded project $(<0.05)$ and being a newly founded 
municipality $(<0.05)$. More specifically, we found that coercive institutional pressure to implement accrual-based rules may become a potent force when a supreme audit institution has control and there is resource dependence on an international body. Simultaneously, we contributed to the literature by adding new institutional emerging country-like variables, as noted by Carpenter and Feroz (2001). Our study suggests that newly founded municipalities and municipalities funded by the EU may apply accrual-based rules to be more legitimate and successful.

The compliance level is $61.2 \%$ for 102 municipalities, which may indicate that reforms have (to some extent) hit their targets. The general reasons that may account for implementation shortfalls are the following: Audits are only performed by the Court of Accounts, and municipalities are not audited every year. There is no legal establishment for the audit of municipalities other than the Court of Accounts. No penalty is imposed on municipalities that do not comply with the accrual accounting-based rules. There is no guidance for staff to ease the implementation of accrual-based rules where such rules create extra work and (in particular) increased stress levels on the part of the staff. In addition, a clear objective for the new accounting system was never formulated by the Turkish legislature. The only argument for the reform is the need for change in the budget accounting system, and no preliminary research on municipalities' needs and shortages was conducted before the transition to accrual-based rules.

Based on this result, we strongly suggest a new design for the public-sector audit. The push for independent financial auditing independent of the Turkish Court of Accounts is also consistent with the current agenda of international bodies. Including the private sector in the process when the public audit is inadequate will obviously increase the level of compliance. Moreover, the role of professional and academic bodies may play an important role in implementing accrual accounting. In addition, according to Smoke (2015), implementation is often neglected and the state must decide how to deal with new functions. In Turkey, many accounting societies play an important role in developing accounting but do not play an active role in the public sector. This may be due to the penetration problem suffered by the public sector. The creation of a public-sector study group may play an important role in solving accrual accounting implementation problems.

"Logically, before talking about the improved information that comes with the implementation of accrual-based rules, we should find the right person who can efficiently and effectively administer them" (Ouda, 2004). Otherwise, the implementation of accrual accounting in the public sector will provide superfluous information that will not be used, and the targeted benefits will not be achieved (Ouda, 2004). The relative relation between compliance level and citizen educational level is a good indicator for introducing a more informative public accounting system. In short, governments should shift from a public administration system to a public management system in parallel with the implementation of accrual accounting rules unless the information provided by accrual accounting is superfluous to traditional public administration.

There remain several unanswered questions regarding the level of compliance; these are matters for further study. The effect of bureaucratic management culture, political factors, and information technology (Ouda, 2008) may be studied to assess the level of compliance. In addition, in almost all of the studies, it is easier to discover "what has been done" rather than "what has been obtained" (Sezen, 2011, p. 326). One could also argue that the good governance version of good or effective government is a hollow for developing countries (Andrews, 2010, p. 7). The real effect of the reforms or rules in question may be examined in further research. Indeed, it is more important to benefit from complying with accrual-based accounting than to achieve a score of $61.2 \%$ on the compliance index. Such a study may constitute a subject for further investigation.

\section{References}

Allen, A., \& Sanders, G. D. (1994). Financial disclosure in US municipalities: has the Governmental Accounting Standards Board made a difference? Financial Accountability \& Management, 10(3), 175-193. doi:10.1111/j.1468-0408.1994.tb00228.x.

Andrews, M. (2010). Good government means different things in different countries. Governance, 23(1), 7-35. doi:10.1111/j.14680491.2009.01465.x. 
Andrews, M. (2012). The logical limits of best practice administrative solutions in developing countries. Public Administration and Development, 32(2), 137-153. doi:10.1002/pad.622.

Antipova, T., \& Bourmistrov, A. (2013). Is Russian public sector accounting in the process of modernization? An analysis of accounting reforms in Russia. Financial Accountability \& Management, 29(4), 442-478. doi:10.1111/faam.12021.

Baker, R. O. N., \& Rennie, M. D. (2006). Forces Leading to the Adoption of Accrual Accounting by the Canadian Federal Government: An Institutional Perspective. Canadian Accounting Perspectives, 5(1), 83-112. doi:10.1506/206k-rv7l-2jmn-w3d3.

Ball, A., \& Craig, R. (2010). Using neoinstitutionalism to advance social and environmental accounting. Critical Perspectives on Accounting, 21(4), 283-293. doi:10.1016/j.cpa.2009.11.006.

Barton, A. (1999). Public and Private Sector Accounting-The Non-identical Twins. Australian Accounting Review, 9(18), 22-31. doi:10.1111/j.1835-2561.1999.tb00105.x.

Bunget, O. C., Blidisel, R. G., Feleaga, L., \& Popa, I. E. (2014). Empirical study of intangible assets in romanian municipalities. E\&M Ekonomie a Management, 17(3), 136-151. doi:10.15240/tul/001/2014-3-011.

Buylen, B., \& Christiaens, J. (2014). Why are some Flemish municipal party group leaders more familiar with NPM principles than others? Assessing the influence of individual factors. Lex Localis, 12(1), 79-103. doi:10.4335/12.1.79-103(2014).

Carlin, T. M. (2005). Debating the impact of accrual accounting and reporting in the public sector. Financial Accountability and Management, 21(3), 309-336. doi:10.1111/j.0267-4424.2005.00223.x.

Carnegie, G. D., \& Wolnizer, P. W. (1995). The financial value of cultural, heritage and scientific collections: an accounting fiction. Australian Accounting Review, 5(9), 31-47. doi:10.1111/j.1835-2561.1995.tb00164.x.

Carnegie, G., \& Wolnizer, P. (1999). Unravelling the rhetoric about the financial reporting of public collections as assets. Australian Accounting Review, 9(17), 16-21. doi:10.1111/j.1835-2561.1999.tb00095.x.

Carpenter, V. L., \& Feroz, E. H. (2001). Institutional theory and accounting rule choice: an analysis of four US state governments' decisions to adopt generally accepted accounting principles. Accounting, Organizations and Society, 26(7), 565-596. doi:10.1016/s0361-3682(00)00038-6.

Chan, J. L. (2006). IPSAS and government accounting reform in developing countries. In E. Lande \& J-C Scheid (Eds.), Accounting Reform in the Public Sector: Mimicry, Fad or Necessity (pp. 31-42). Paris: Expert Comptable Media.

Cheng, R. H. (1992). An empirical analysis of theories on factors influencing state government accounting disclosure. Journal of Accounting and Public Policy, 11(1), 1-42. doi:10.1016/0278-4254(92)90013-n.

Christensen, M. (2007). What We MightKnow (But Aren't Sure) About Public-Sector Accrual Accounting. Australian Accounting Review, 17(1), 51-65. doi:10.1111/j.1835-2561.2007. tb00453.x.

Christensen, M., \& Parker, L. (2010). Using ideas to advance professions: public sector accrual accounting. Financial Accountability \& Management, 26(3), 246-266. doi:10.1111/j.1468-0408.2010.00501.x.

Christiaens, J. (1999). Financial accounting reform in Flemish municipalities: an empirical investigation. Financial Accountability \& Management, 15(1), 21-40. doi:10.1111/14680408.00072.

Christiaens, J., \& Rommel, J. (2008). Accrual accounting reforms: only for businesslike (parts of) governments. Financial Accountability \& Management, 24(1), 59-75. doi:10.1111/j.14680408.2008.00443.x.

Christiaens, J., \& Vanhee, C. (2003). Accounting Reform in Flemish Municipalities: an Empirical Study of the Evolution of the Outcomes. In EAA 26th annual Congress.

Christiaens, J., \& Van Peteghem, V. (2007). Governmental accounting reform: evolution of the implementation in Flemish municipalities. Financial Accountability \& Management, 23(4), 375-399. doi:10.1111/j.1468-0408.2007.00434.x.

Cohen, J., Cohen, P., West, S. G., \& Aiken, L. S. (2013). Applied Multiple Regression/ Correlation Analysis for the Behavioral Sciences. Routledge.

Coy, D., \& Dixon, K. (2002, April). The public accountability disclosure index (PAI): an index with parametric statistical power to measure the quality of annual reports. In Annual Conference of the British Accounting Association.

Coy, D., \& Dixon, K. (2004). The public accountability index: crafting a parametric 
disclosure index for annual reports. The British Accounting Review, 36(1), 79-106. doi:10.1016/j.bar.2003.10.003.

Coy, D., Tower, G., \& Dixon, K. (1994). Public sector reform in New Zealand: The progress of tertiary education annual reports, 199092. Financial Accountability \& Management, 10(3), 253-261. doi:10.1111/j.1468-0408.1994. tb00232.x.

Da Costa Carvalho, J. B., Camões, P. J., Jorge, S. M., \& Fernandes, M. J. (2007). Conformity and diversity of accounting and financial reporting practices in Portuguese local government. Canadian Journal of Administrative Sciences/Revue Canadienne des Sciences de l'Administration, 24(1), 2-14. doi:10.1002/cjas.1.

Delegation of European Union to Turkey, retrieved June, 172014 from http://www. avrupa.info.tr/AB_Mali_Destegi.html

DiMaggio, P. J., \& Powell, W. W. (1983). The iron cage revisited-Institutional isomorphism and collective rationality in organizational fields (Reprinted from the American Sociological Association, 48, 147-160). Advances in Strategic Managment, 2000, 17(17), 143-166. doi:10.2307/2095101.

DiMaggio, P. J., \& Powell, W. W. (Eds.). (1991). The new institutionalism in organizational analysis (Vol. 17). Chicago, IL: University of Chicago Press. doi:10.1177/000169939303600107.

Dixon, K., Coy, D., \& Tower, G. (1991). External reporting by New Zealand universities 1985-1989: Improving accountability. Financial Accountability \& Management, 7(3), 159-178. doi:10.1111/j.1468-0408.1991.tb00348.x.

English, L., Guthrie, J., \& Carlin, T. (2000, March). Transformation of public sector financial management: reflection on the Victorian experience downunder. In EAA 23rd Annual Congress (Munich, Germany).

Evans, J. H., \& Patton, J. M. (1983). An economic analysis of participation in the municipal finance officers association certificate of conformance program. Journal of Accounting and Economics, 5, 151-175. doi:10.1016/01654101(83)90009-5.

Evans, J. H., \& Patton, J. M. (1987). Signaling and monitoring in public-sector accounting. Journal of Accounting Research, 25, 130-158. doi:10.2307/2491083.

Faul, F., Erdfelder, E., Lang, A. G., \& Buchner, A. (2007). G* Power 3: A flexible statistical power analysis program for the social, behavioral, and biomedical sciences. Behavior Research Methods, 39(2), 175-191. doi:10.3758/bf03193146.

Froelich, K. A. (1999). Diversification of revenue strategies: Evolving resource dependence in nonprofit organizations. Nonprofit and Voluntary Sector Quarterly, 28(3), 246-268. doi:10.1177/0899764099283002.

Giroux, G. (1989). Political interests and governmental accounting disclosure. Journal of Accounting and Public Policy, 8(3), 199-217. doi:10.1016/0278-4254(89)90004-5.

Giroux, G., \& McLelland, A. J. (2003). Governance structures and accounting at large municipalities. Journal of Accounting and Public Policy, 22(3), 203-230. doi:10.1016/s02784254(03)00020-6.

Gomes, P. S., Fernandes, J. M., \& Da Costa Carvalho, J. B. (2015.) The International Harmonization Process of Public Sector Accounting in Portugal: The Perspective of Different Stakeholders. International Journal of Public Administration, 38(4), 268-281. doi:10.1080/01900692.2015.1001237.

Greening, D. W., \& Gray, B. (1994). Testing a model of organizational response to social and political issues. Academy of Management Journal, 37(3), 467-498. doi:10.2307/256697.

Guler, I., Guillén, M. F., \& Macpherson, J. M. (2002). Global competition, institutions, and the diffusion of organizational practices: The international spread of ISO 9000 quality certificates. Administrative Science Quarterly, 47(2), 207-232. doi:10.2307/3094804.

Guo, C. (2007). When government becomes the principal philanthropist: The effects of public funding on patterns of nonprofit governance. Public Administration Review, 67(3), 458-473. doi:10.1111/j.1540-6210.2007.00729.x.

Harun, H., \& Robinson, P. (2010). The adoption of accrual accounting in the Indonesian public sector. Research in Accounting in Emerging Economies, 10, 233-250. doi:10.1108/s1479-3563(2010)0000010014.

Hillman, A. J., Withers, M. C., \& Collins, B. J. (2009). Resource dependence theory: A review. Journal of Management, 35(6), 1404-1427. doi:10.1177/0149206309343469.

Hofstede, G. (1983). The Cultural Relativity of Organizational Practices and Theories. Journal of International Business Studies, 14(2), 75-89. doi:10.1057/palgrave.jibs.8490867.

Ingram, R. W. (1984). Economic incentives and the choice of state government accounting 
practices. Journal of Accounting Research, 126-144. doi:10.2307/2490704.

Ingram, R. W., \& Copeland, R. M. (1981). Disclosure practices in audited financial statements of municipalities. Public Budgeting \& Finance, 1(2), 47-58. doi:10.1111/1540-5850.00515.

Ingram, R. W., \& DeJong, D. V. (1988). The effect of regulation on local government disclosure practices. Journal of Accounting and Public Policy, 6(4), 245-270. doi:10.1016/ s0278-4254(87)80002-9.

Kablan, A. (2013). Financial Resources of Municipalities in Turkey. International Journal of Finance \& Banking Studies, 2(1), 21-30.

Lapsley, I., \& Pallot, J. (2000). Accounting, management and organizational change: A comparative study of local government. Management Accounting Research, 11(2), 213229. doi:10.1006/mare.2000.0129.

Martí, C., \& Kasperskaya, Y. (2015). Public Financial Management Systems and Countries' Governance: A Cross-Country Study. Public Administration and Development. 35(3), 165178. doi:10.1002/pad.1711.

Marwata, \& Alam, M. (2006). The interaction amongst reform drivers in governmental accounting changes: the case of Indonesian local government. Journal of Accounting \& Organizational Change, 2(2), 144-163. doi:10.1108/18325910610675989.

McLeod, R. H., \& Harun, H. (2014). Public Sector Accounting Reform at Local Government Level in Indonesia. Financial Accountability \& Management, 30(2), 238-258. doi:10.1111/ faam.12035.

Meyer, J. W., \& Rowan, B. (1977). Institutionalized organizations: Formal structure as myth and ceremony. American journal of sociology, 83(2), 340-363. doi:10.1086/226550.

Micallef, F. (1994). A new era in reporting by government departments. Australian Accountant, 64(2), 33-34.

Mizruchi, M. S., \& Fein, L. C. (1999). The social construction of organizational knowledge: A study of the uses of coercive, mimetic, and normative isomorphism. Administrative Science Quarterly, 44(4), 653683. doi:10.2307/2667051.

Müftüler Baç, M. (2005). Turkey's political reforms and the impact of the European Union. South European Society and Politics, 10(1), 1731. doi:10.1080/13608740500037916.

Müftüler-Baç, M. (2008). Turkey's accession to the European Union: The impact of the EU's internal dynamics. International Studies Perspectives, 9(2), 201-219. doi:10.1111/j.1528-3585.2008.00327.x.

Nor-Aziah, A. K., \& Scapens, R. W. (2007). Corporatisation and accounting change: The role of accounting and accountants in a Malaysian public utility. Management Accounting Research, 18(2), 209-247. doi:10.1016/j.mar.2007.03.003.

Organizzazione per la cooperazione e lo sviluppo economici: Public management committee. (1997). Issues and developments in public management, survey 1996-1997. Organisation for Economic Co-operation and Development.

Oliver, C. (1991). Strategic responses to institutional processes. Academy of Management Review, 16(1), 145-179. doi:10.5465/amr.1991.4279002.

Ouda, H. (2004). Basic requirements model for successful implementation of accrual accounting in the public sector. Public Fund Digest, 4(1), 78-99.

Ouda, H. (2005). Additional transition problems of accrual accounting in the public sector of developing countries. Public Fund Digest, 5(1), 92-99.

Ouda, H. (2008). Towards a Generic Model for Government Sector Reform: the New Zealand Experience. International Journal Financial Management, 8(2), 78-100.

Pallot, J. (1994). The development of accrual-based accounts for the government of New Zealand. Advances in International Accounting, 7(2), 287-308.

Palmer, D. P., Jennings, D., \& Zhou, X. (1993). Late adoption of the multidivisional form by large U.S. corporations: Institutional, political, and economic activity. Administrative Science Quarterly, 38(1), 100-131. doi:10.2307/2393256.

Pfeffer, J., \& Salancik, G. R. (1978). The external control of organizations: A resource dependence perspective. Stanford University Press.

Pina, V., \& Torres, L. (1996). An international comparison of governmental annual reports. Research in Governmental and Nonprofit Accounting, 123-146.

Pina, V., \& Torres, L. (2003). Reshaping public sector accounting: an international comparative view. Canadian Journal of Administrative Sciences, 20(4), 334-350. doi:10.1111/j.1936-4490.2003.tb00709.x. 
Pina, V., Torres, L., \& Yetano, A. (2009). Accrual accounting in EU local governments: One method, several approaches. European Accounting Review, 18(4), 765-807. doi:10.1080/09638180903118694.

Pollanen, R., \& Loiselle-Lapointe, K. (2012). Accounting reform in the government of Canada: Exploratory evidence on accrual accounting adoption and impact. Financial Accountability \& Management, 28(4), 359-377. doi:10.1111/j.1468-0408.2012.00551.x.

Pollitt, C. (2001). Clarifying convergence. Striking similarities and durable differences in public management reform. Public Management Review, 3(4), 471-492. doi:10.1080/14616670110071847.

Robins, W. A., \& Austin, K. R. (1986). Disclosure quality in governmental financial reports. Journal of Accounting Research, 24(2), 412-421. doi:10.2307/2491145.

Ryan, C. (1998). The introduction of accrual reporting policy in the Australian public sector: an agenda setting explanation. Accounting, Auditing \& Accountability Journal, 11(5), 518-539. doi:10.1108/09513579810239837.

Ryan, C., Stanley, T., \& Nelson, M. (2002). Accountability disclosures by Queensland local government councils: 1997-1999. Financial Accountability \& Management, 18(3), 261-289. doi:10.1111/1468-0408.00153.

Saleh, Z. (2007). Malaysian governmental accounting: national context and user orientation. International Review of Business Research Papers, 3(2), 376-384.

Salinas, F. J. (2002). Accrual budgeting and fiscal consolidation in the EMU. Contemporary Economic Policy, 20(2), 193-206. doi:10.1093/ cep/20.2.193.

Scott, W. R. (1987). The adolescence of institutional theory. Administrative science quarterly, 32(4), 493-511. doi:10.2307/2392880.

Sezen, S. (2011). International Versus Domestic Explanations of Administrative Reforms: The Case of Turkey. International Review of Administrative Sciences, 77(2), 322-346. doi:10.1177/0020852311399229.

Shand, D. (1990). Australia moves to accrual accounting: problems and prospects. In J. Forster, \& J. Wanna (Eds.), Budgetary Management and Control: The Public Sector in Australasia (pp. 142-150). Melbourne: MacMillan.

Smoke, P. (2015). Managing Public Sector Decentralization in Developing Countries:
Moving Beyond Conventional Recipes. Public Administration and Development, 35(4), 250262. doi:10.1002/pad.1736.

Sozen, S., \& Shaw, I. (2002). The international applicability of "new" public management: lessons from Turkey. International Journal of Public Sector Management, 15(6), 475-486. doi:10.1108/09513550210439625.

Sozen, S. (2012). Recent administrative reforms in Turkey: a preliminary assessment. International Journal of Business and Social Science, 3(9), 168-173.

Stanley, T., Jennings, N., \& Mack, J. (2008). An examination of the content of community financial reports in Queensland local government authorities. Financial Accountability \& Management, 24(4), 411-438. doi:10.1111/j.1468-0408.2008.00460.x.

Street, D. L., \& Gray, S. J. (2002). Factors influencing the extent of corporate compliance with International Accounting Standards: summary of a research monograph. Journal of International Accounting, Auditing and Taxation, 11(1), 51-76. doi:10.1016/s1061-9518(02)00054-x.

Tooley, S., \& Guthrie, J. (2007). Reporting performance by New Zealand secondary schools: an analysis of disclosures. Financial Accountability \& Management, 23(4), 351-374. doi:10.1111/j.1468-0408.2007.00433.x.

Türkyener, C. M. (2011). The Basic Problems on Financial Reporting and Analysis in the Municipalities. Dış Denetim, 47-58.

Upping, P., \& Oliver, J. (2012). Thai public universities: modernisation of accounting practices. Journal of Accounting \& Organizational Change, 8(3), 403-430. doi:10.1108/18325911211258362.

Verbruggen, S. (2011). Nonprofit Organizations: Financial Reporting, Auditing and Earnings (Unpublished doctoral dissertation). Ghent University, Ghent, Belgium.

Weets, V., \& Jegers, M. (2000). An analysis of financial statement coherence and audit firm quality differences. Tijdschrift voor Economie en Management, 45(3), 339-358.

Windels, P., \& Christiaens, J. (2006). Management reform in Flemish public centres for social welfare: examining organisational change. Local Government Studies, 32(4), 389-411. doi:10.1080/03003930600792864. 
Selver Seda Ada

Ghent University

Suleyman Sah University

Faculty of Economics

and Business Administration

Department of Public Governance,

Management and Finance

selversedaada@gmail.com
Prof. Dr. Johan Christiaens

Ghent University Faculty of Economics

and Business Administration Department of Public Governance, Management and Finance johan.christiaens@ugent.be 


\section{Abstract}

\section{WHY DO SOME MUNICIPALITIES APPLY ACCRUAL-BASED RULES MORE THAN OTHERS? EVIDENCE FROM TURKEY}

\section{Selver Seda Ada, Johan Christiaens}

In the last decades, public sector has been influenced by New Public Management emphasizing incentives, competition, and performance. With the effect of New Public Management, implementation of accrual accounting based rules in the local government level has been studied from different aspects and within different contexts. In this study, we seek to further delineate factors affecting the level of compliance to accrual based accounting rules in the local government level in an emerging country - Turkey. We shed lights on two new emerging country-like variables: implementation of European Union funded projects and newly founded municipalities with six control variables including municipal size, municipal wealth, citizen education level, staff education level, debt ratio and external audit. Data, to be analyzed, is gathered from 102 Turkish municipalities. We use compliance index, consisting of 39 items, in order to assess the level of compliance of the municipalities. Institutional theory and resource dependence theory have been employed in order to increase our understanding on the factors affecting the level of compliance to the accrual based rules. The results show moderate compliance, $61.2 \%$, with the accrual based rules. Predictors that have clearly significant effect on the level of compliance are respectively, the external audit $(b=.123, \beta=.450, p=.000)$, implementation of EU funded projects $(b=.074, \beta=.267, p=.002)$ and being a newly founded municipality $(b=.071, \beta=.155, p=.031)$. Moreover, we found that coercive institutional pressure to implement accrual-based rules may become a potent force when a supreme audit institution has control and there is resource dependence on an international body.

Key Words: Accrual accounting, emerging countries, new public management, public sector reform, Turkey.

JEL Classification: M480, M410, H7.

DOI: 10.15240/tul/001/2017-3-013 